\title{
The Determinants of International Migration in Early Modern Europe: Evidence from the Maritime Sector, c. 1700-1800
}

\author{
[accepted for publication in Social Science History]
}

Alexander Klein

University of Kent

Jelle van Lottum

Huygens Institute for the History of the Netherlands, Royal Netherlands Academy of

Arts and Sciences

\begin{abstract}
This paper offers the first multivariate regression study of international migration in early modern Europe. Using unique eighteenth-century data about maritime workers, we created a data set of migration flows among European countries to examine the role of factors related to geography, population, language, the market and chain migration in explaining the migration of these workers across countries. We show that among all factors considered in our multivariate analysis, the geographical characteristics of the destination countries, size of port towns, and past migrations are among the most robust and quantitatively the most important factors influencing cross-country migration flows.
\end{abstract}

\footnotetext{
${ }^{1}$ The work underlying this article was made possible by a grant from the Economic and Social Research Council (ESRC) (RES-062-23-3339: "Migration, human capital and labour productivity: The international maritime labour market in Europe, c. 1650-1815"). An earlier version of this paper was presented at the annual conference of the Economic History Society in London in April 2017. We would like to thank the participants in our session for their valuable input.
} 


\section{Introduction}

Sweden-born Lourens Alström served as a common seaman aboard the Dutch merchant vessel De Vleyt [Industriousness] when in March 1781 it was taken by the British Navy, of the Cornish coast, as a (potential) prize of war. Having been brought to the coastal town of Penryn, Alström was subsequently interrogated by a clerk of the High Court of Admiralty, a standard, strictly formalised procedure aimed at determining the legality of the seizing of the ship. The seaman was questioned about various relating to the ship and its cargo, but also about her crew, and indeed about himself. Alström declared that he was born in the Swedish capital of Stockholm in 1741, but for the last eight years had lived in Amsterdam in the Netherlands. From his testimony we know that he was not the only labour migrant aboard the Dutch ship. Six men came from Germany, two from Sweden (Alström included) and only one came from Holland. Two colleagues who were also interrogated also declared to have migrated to Amsterdam. The captain of the ship, Claas Eehlers, born in Cuxhaven in Germany, declared to have lived in Amsterdam since 1759; he even received official citizenship there. Jacob Faber, who like Alström also served as a common sailor aboard De Vleyt was born in the Southern Swedish town of Kalmar, and had also moved to Amsterdam in the decade before 1781 .

The migration histories of Alström, Eehler and Faber are anything but exceptional: migration was a common feature of pre-industrial societies. Because the vast majority of migrations took place within the confines of a country, a province or even a parish, in most cases such moves occurred over relatively short distances. However, long-distance migrations, which, like in the case of the three mariners described above, involved moves of hundreds of kilometres or more, often resulting in individuals entering foreign territories, were hardly rare (Hoerder, 2002; Page Moch 2003; Manning 2005; Van Lottum 2007; Bade et al. 2013). Recent estimates show that international mobility levels increased strongly after the medieval period, 
peaking in the late seventeenth century. In the latter half of the seventeenth century an estimated eight percent of European individuals (residents of Russia excluded) could be considered an international migrant (Lucassen and Lucassen 2009). These numbers were surpassed only during the mass migrations to the New World in the nineteenth century (Hatton and Williamson 2008). Impressive as they may be, such estimates underplay the impact of international migration in economic core regions, which were invariably located in urban areas. For instance, in Amsterdam around 1700 - at the time still one of early modern Europe's key economic centres - no less than 40 percent of its population had been born abroad (Lucassen 2002). In the sending countries the impact was large, too; around 1650, one in every ten individuals born in Scotland was living abroad (Van Lottum 2007).

Traditionally, studies on early modern international migration in Europe focus on two groups in particular: refugees and elite migrant groups (or individuals from them). ${ }^{2}$ Notwithstanding the substantial cultural and economic importance of these migrant groups, in reality they constituted only a fraction of Europe's internationally mobile population (Lucassen 2012). Not unlike in the industrial (and post-industrial) era, during the early modern period international migration consisted mostly of men and women travelling from one country to another in search of work or economic betterment. This internationally mobile group included a variety of occupations that are usually labelled as unskilled or semi-skilled: domestic

\footnotetext{
${ }^{2}$ Famous refugee migrations include those of Protestant Huguenots who fled persecution in seventeenth- and eighteenth-century France to various cities in northwestern Europe (Schilling 1983; Pettegree 1986; Cottret 1991), and the Southern Netherlanders who moved from the Spanish Netherlands to the young Dutch Republic in the late sixteenth and early seventeenth centuries (Gelderblom 2000). An earlier example is the well-documented Jewish diaspora from the Iberian Peninsula following the Alhambra Degree in 1492 (Israel 1985; Ruderman 2010). Other, no less conspicuous migrations given ample attention in the historiography are those of (international) merchants and other prominent migrant groups comprising scientists, intellectuals and artists (Bade et al. 2011).
} 
servants, artisan journeymen, petty traders, cobblers, day labourers, soldiers as well as the group that is the focus of this study, seamen (Moch 2003).

The international migrations of 'common men and women' in pre-industrial Europe have been receiving scholarly attention in recent years. Insights have been gained into the relationship between international migration and social change (Lucassen and Lucassen, 2017), into processes of integration and assimilation (Moch 2003; Kuijpers 2005; Sogner 1993), and the mapping of key migration routes on the continent (Van Lottum 2007), but also to other parts of the world, in particular to North America (Wokeck 1999; Grubb 2011; Wegge 1998, 1999, 2017, 2018).

In stark contrast to studies covering the nineteenth century (e.g. Baines 1994; Hatton and Williamson 2008), there are few quantitative studies analysing the drivers of international labour migration in the preceding era. This is primarily caused by a lack of sources that allow a rigorous assessment of the causes of migration. The early modern maritime sector is one of the best documented sectors of early modern Europe (Lucassen and Unger 2011; Van Royen et al. 1997), characterised by substantial international migration, and as far as we are aware it is the only sector that allows the creation of migration flows between early modern European countries using a single source: the Prize Papers Archive, the collection which holds the interrogations of captured crews we began this paper with. This source offers a unique opportunity to assess the determinants of international labour mobility before the onset of the Industrial Revolution.

\section{Migration and the early modern maritime sector}

The maritime sector was a key sector of the European economy. Pre-industrial Europe was still very much dependent on processes of commercialisation to bring about economic growth 
(Acemoglu et al. 2005). As a result it was highly dependent on (cheap) transport. Not surprisingly, the shipping sector was therefore a sizeable employer in most seafaring nations, and often one of the larger - if not the largest - provider of work in coastal regions. The large demand for seamen in port cities, large and small, lured not only locally raised men and boys to their ships, however. Because demand often outstripped domestic supply, from the late seventeenth century onwards the sector increasingly had to rely on foreign workers (Van Royen et.al 1997).

Two general features of the maritime labour market were fundamental in facilitating the international migration of seamen. First, although in some southern European countries institutional barriers existed that could prohibited foreigners from entering service and even when formally foreigner allowed, informal preferences could hamper their career chances (cf. Rahn-Phillips 1997), overall the early modern maritime sector was characterised by relatively few obstacles to hamper maritime workers' freedom of movement. Second, this was a sector in which free modes of recruitment were the most common; most seamen were wage labourers, and substantial wage differences provided incentives for mobility - within individual states and internationally (Lucassen, 1997).

Although the share of foreign labour participation changed over time and could differ substantially between countries - northwestern European countries generally had a higher proportion of immigrant workers among their crews than the Mediterranean nations - during the eighteenth century there were few labour markets that relied solely on a national labour supply. Basques served aboard English ships, Italian seamen sailed on French merchant vessels, and Norwegians, Germans and Swedes manned the Dutch mercantile fleet in large numbers - as indeed the crew of De Vleyt illustrates.

Figure 1: Recruitment areas of four maritime centres in north-western Europe. 
Amsterdam and Rotterdam, c. 1700
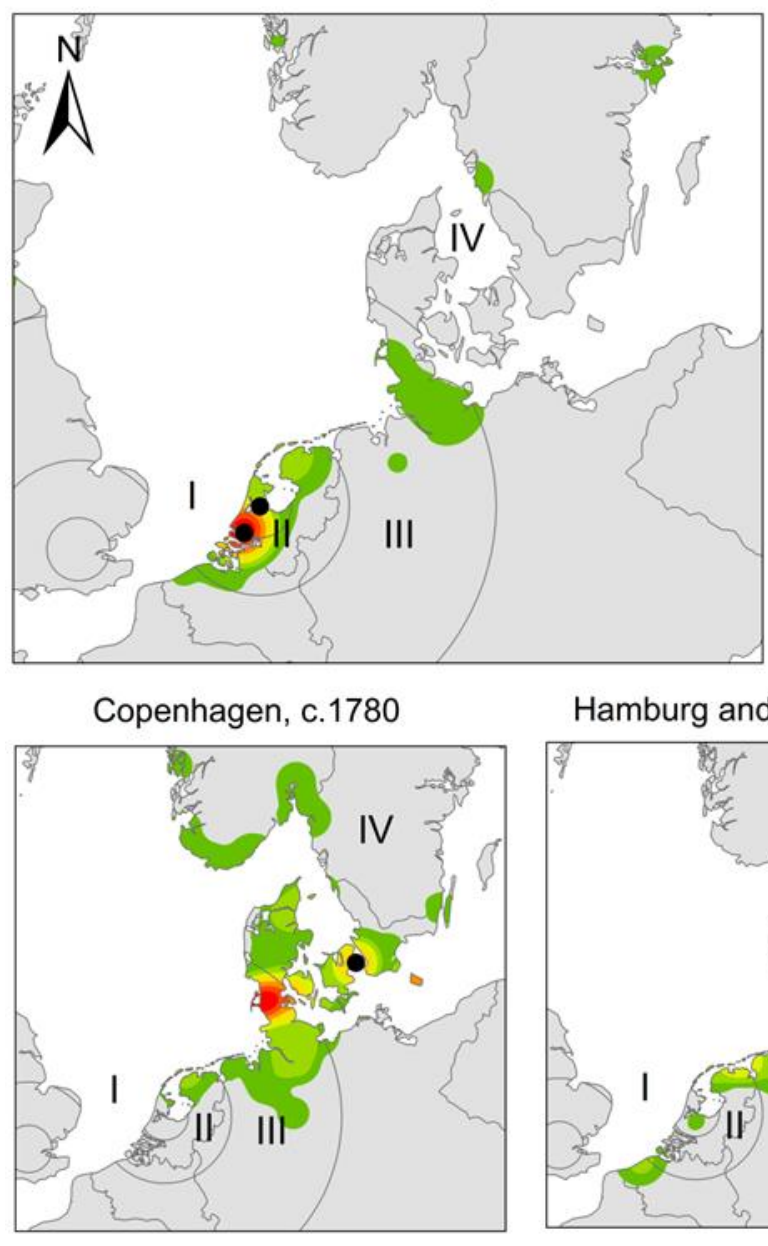

Amsterdam and Rotterdam, c. 1780

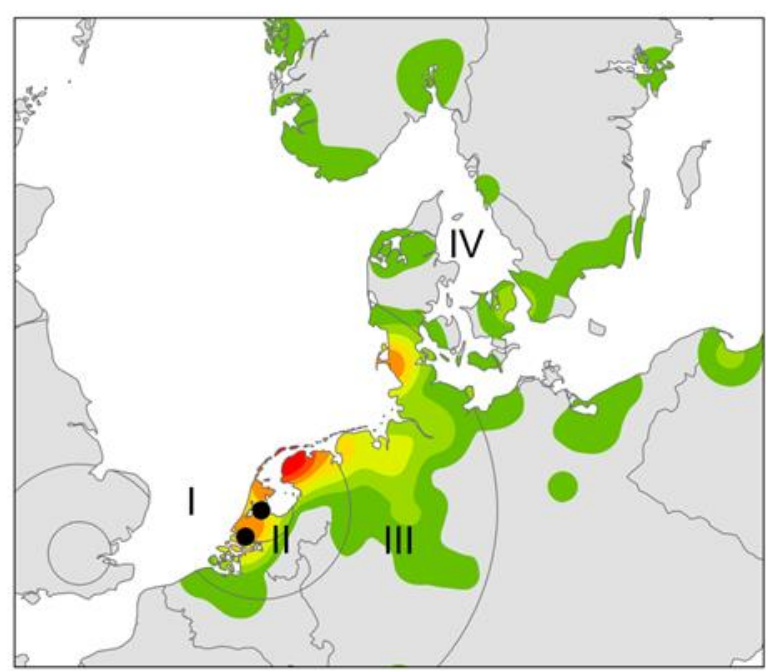

Hamburg and Bremen, c. 1780
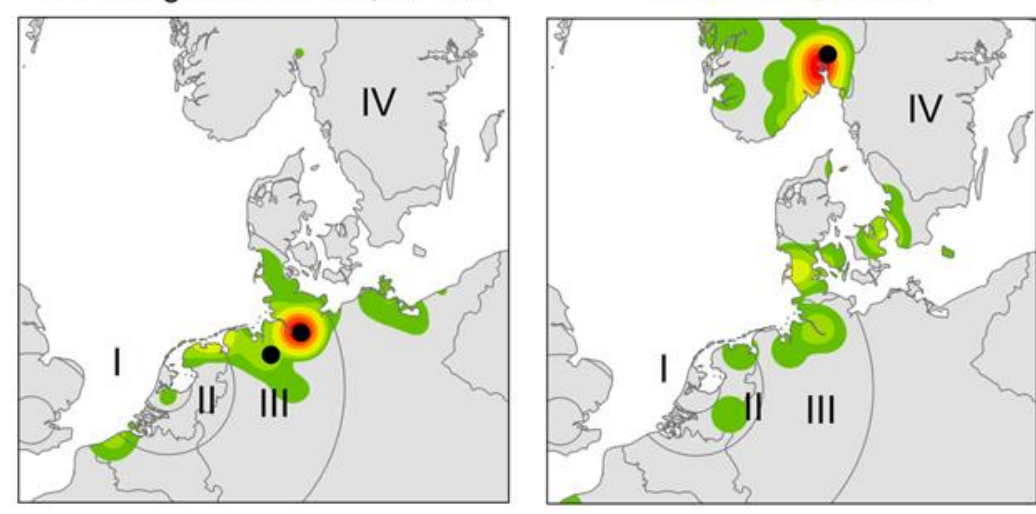

Source: Van Lottum, 2015; Prize Paper Database.

The data drawn from the Prize Paper Dataset shows that already by 1700 domestic maritime labour markets relied to a large extent on foreign workers, but that the labour markets further internationalised throughout the century: in 170024 percent of all crews consisted of non-native born workers, by 1800 this was 32 percent. Figure 1 provides a good illustration of the international character of the European maritime sector during the eighteenth century. The maps, which are all so-called kernel density maps (or 'heat maps', to use the colloquial term), depict the hinterlands of four important maritime hubs, with the red regions signifying areas of highest concentration. The upper two maps show the origins of maritime workers on ships hailing from key maritime ports in the Netherlands (Rotterdam and Amsterdam) in 1700 and 
1800. The bottom three show the same information for Denmark (Copenhagen), Germany (Hamburg) and Norway (Christiania, present-day Oslo) in 1800. The two maps illustrating the hinterland Netherlands comfirmed that during the eighteenth century the level of foreign labour participation could indeed change substantially. Around 1700 ships hailing from Amsterdam and Rotterdam attracted only a modest number of seamen from abroad; most came from within the nation's borders. A century later their hinterland had, however, expanded significantly: it attracted a large share of its labour force from (nearly all) coastal regions in northwestern Europe. The other three maritime centres show similarly expansive hinterlands around the same time. Hamburg and Bremen attracted migrants from as far as present-day Belgium; Christiania drew migrants not only from Denmark but also from the Netherlands: and Swedes, Norwegians, Germans and Dutchmen were all employed on board ships sailing from Copenhagen.

\section{Dataset}

To uncover the drivers behind the international migration in the eighteenth century maritime sector this paper makes use of the Prize Paper Dataset (PPD), a dataset containing a variety of data relating to the eighteenth-century maritime sector. The initial data collection took place as part of the Economic and Social Research Council (ESRC) -funded project "Migration, human capital and labour productivity: The international maritime labour market in Europe, c. 1650$1815, " 3$ and has been coded and standardized. The dataset has been used in a number of studies, including assessments of human capital and labour productivity levels in the eighteenth-century maritime sector (Van Lottum and Van Zanden 2014). The PPD uses data derived from a section

\footnotetext{
${ }^{3}$ The dataset can be accessed at the UK Data Service: http://reshare.ukdataservice.ac.uk/852135/
} 
of the archive of the High Court of Admiralty (HCA), kept at The National Archives (TNA) in Kew Gardens, UK, concerning the interrogation of persons on board of those ships taken as 'prizes' by the British Navy or private men-of-war (TNA HCA 32) (Van Lottum et.al 2011). When a Royal Navy vessel or a private man-of-war captured an enemy ship, a court needed to establish whether the vessel was in fact a lawful prize: in other words whether the ship, crew or cargo belonged to an enemy state. To determine this, we touched upon this earlier, crew members were cross-examined (if necessary with the help of a sworn-in interpreter) about all matters relating to the ownership of the ship and its cargo. Commonly, like in the case of the Dutch vessel that featured in our introduction, three crew members were questioned, usually a cross section of the ranks aboard.

From the interrogations, the PPD was created, containing all the information required by the interrogation rubric and therefore consistently present in the interrogations. The database comprises two tables, one of which deal with information about the ship, such as geographical markers of its ports of origin and destination, its tonnage, the number of nationalities aboard and information about its owner. This is linked to information about the crew, since there was normally more than one crew member interrogated per vessel. The crew table includes demographic information about the individual interrogated, among others about place (and therefore country) of birth and residence (as we will explain this information we used to calculate migration flows), but also indicators of literacy, and rank and the length and nature of his relationship with the master of the vessel. The PPD contains circa fifteen thousand individual individuals who served aboard more than four thousand ships in a span of time that covers different periods between 1702 and 1803. In this paper we focus on two periods from the dataset, each covering a period of similar length of about a decade. Period 1 covers the start 
of the eighteenth century, from 1702 to 1712; Period 2 begins in the last decade of the eighteenth century and extends into the nineteenth: $1793-1803 .^{4}$

Given the fact that crews were interrogated during times of international conflict (interrogations indeed only exist for periods in which England (or Britain) was at war), an important issue is the extent to which the data from the PPD provides a normal representation of migratory behaviour. We also believe that it does. First, the interrogations generally provided accurate information about the ships and crews. Those who were interrogated will have been aware (or made aware) that answers given in the interrogations could be verified with relative ease by the court. All ships' papers were confiscated and used in the eventual court case at the High Court of Admiralty in London.

Second, although the data indeed derives from a period of war, we believe that it is comparable with the situation of the sector in peace time. Earlier research has shown that estimates of labour productivity of ships derived from the PPD were similar to those taken in peace time. ${ }^{5}$ The same applies to levels of migration. Comparison between the general trends of international migration in early modern Europe and studies focused on international migration to specific countries show that the size and direction of migration flow match well with those constructed using the PPD. An example of the latter is provided in Table 1 below, in which we compare data from the PPD to Lucassen's (2002) estimates of the size of four migrant communities in the province of Holland (based a range of [in particular] civic sources). The latter study is one of the few studies that provides a reliable national estimate of immigration levels for the early modern era. Applying the same categorisation as Lucassen, Table 1 shows that the PPD provides largely similar figures. Not only does the overall share of

\footnotetext{
${ }^{4}$ The choice for these periods is based on the fact that each period covers a decade of interrogations.

${ }^{5}$ Van Lottum and Van Zanden (2014).
} 
foreigners in Holland match Lucassen's estimate, but the size of the individual migration flows are also largely similar.

Table 1: Countries of origins of residents in eighteenth century Dutch Republic, based on the PPD (PERIOD 2 and the Lucassen estimates

\begin{tabular}{lcc}
\hline Country or countries of birth & $P P D$ & Lucassen estimates \\
\hline Belgium and France & $1,7 \%$ & $1,8 \%$ \\
Germany & $13,4 \%$ & $11,4 \%$ \\
England and Scotland & $2,1 \%$ & $0,4 \%$ \\
Other countries (chiefly Scandinavian & $6,6 \%$ & $3,8 \%$ \\
countries) & & \\
Foreign-born residents & $23,8 \%$ & $17,5 \%$ \\
Native born & $76,2 \%$ & $82,5 \%$ \\
\hline
\end{tabular}

Source: Prize Paper Dataset and Lucassen, 2002: p. 22.

Note: the figures are based on the combined survey years 1700, 1750 and 1800 in Lucassen (2002) and the combined Periods 1 and 2 in the PPD.

The dataset covers a broad geographical range. Because ships could carry a false flag, British privateers - who operated in all European seas $-{ }^{6}$ seized nearly every ship they came across, regardless of the true nation of origin. As a result the archive covers ships and crews from all maritime nations in the north Atlantic. This includes Britain itself - ships taken by an enemy ships that were subsequently retaken had to follow the standard interrogation given to crew members of all other ships. As a result, the PPD covers all maritime nations in Europe. This is shown in Figure 2, which depicts the places of origin of crews in the PPD born in Europe.

Figure 2: Place of origin of ships and crews in the Prize Paper Dataset

\footnotetext{
${ }^{6}$ Ships were captured not only in the waters surrounding the United Kingdom, but also near to English interests in the Mediterranean, such as the Canary Islands, Livorno, or Menorca. Other captures were done as far away as the Indian Ocean, in the Bay of Bengal, off the Cape coast and west coast of Africa.
} 

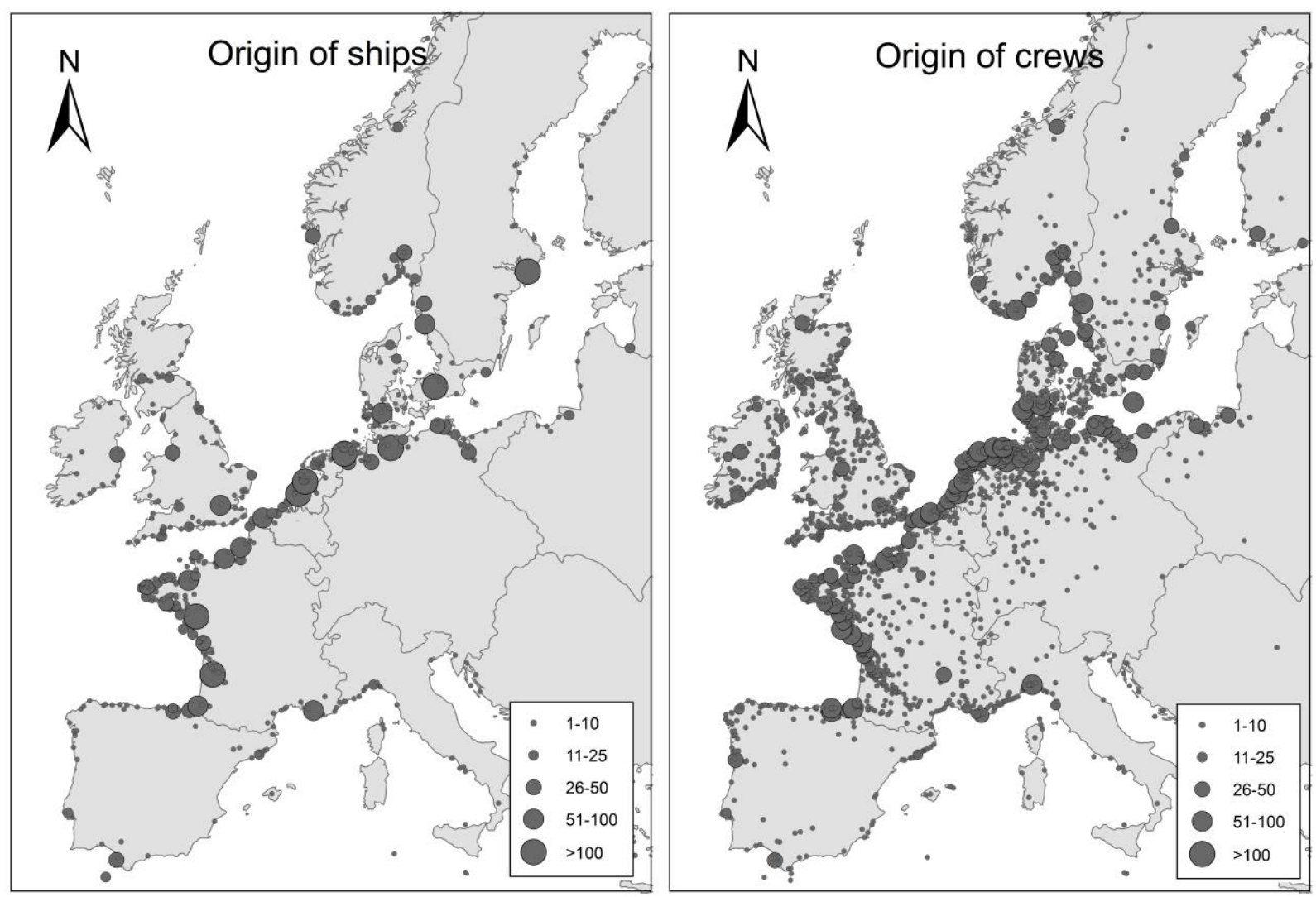

Immigration rates, the dependent variable in our analysis, is derived from the PPD. Based on standardised categories to register countries of birth, residence and employment, all individuals in the PPD have been assigned a migration code: N, M or NRM. Native maritime workers $(\mathrm{N})$ lived and worked in their country of birth, migrant maritime workers (M) lived and worked in a country other than their country of birth, while non-resident migrants (NRM) resided in their country of birth but worked for foreign employers (in the migration literature they are often referred to as temporary workers) (Lucassen, 1987). In our analysis we focus solely on the sedentary $\mathrm{M}$ category, which we use to calculate the size of flows of migrant maritime workers between pairs of countries - i.e., from country of birth to country of residence. The three seamen we briefly discussed in the introduction are also examples of this categories: Alström and Faber were born in Sweden, Eehler in Germany, and all three moved to Amsterdam and settled there later in their careers. 
As there were significant changes in national territories between the beginning and end of the eighteenth century we have used present-day borders instead of historical ones. Despite the obvious anachronisms (Belgium, for instance, did not yet exist, nor was there a unified Germany), this will not hamper our analysis; we believe the use of modern borders allows for a more consistent comparison of the migration flows between the beginning and end of the eighteenth century. For Period 1 (c.1700) our analysis is based on 77 country pairs, consisting of 14 recipient countries; Period 2 (c.1800) consists of 94 country pairs and 19 recipient countries. $^{7}$

\section{Explanatory Variables}

The migration of maritime workers has here been analysed from the vantage point of the destination countries. In our regression model, the migration rates in ca. 1700 and 1800 , respectively, are related to nine independent variables. These can be subsumed within four broader groups of explanatory variables: market characteristics, geographical characteristics, population and linguistic characteristics, and stock of previous migrants. Table 2 offers the definitions of each variable.

\footnotetext{
${ }^{7}$ Using present-day borders and names this involves the following countries: 1700: Belgium, Denmark, England, France, Germany, Ireland, Italy, the Netherlands, Norway, Poland, Portugal, Scotland, Spain, Sweden. 1800: Belgium, Denmark, England, France, Germany, Ireland, Northern Ireland, Italy, Lithuania, the Netherlands, Norway, Poland, Portugal, Scotland, Spain, Sweden, Switzerland, Ukraine, Wales.
} 
Table 2. Description of variables

\begin{tabular}{|c|c|}
\hline Variables & Definition \\
\hline \multicolumn{2}{|l|}{ Dependent variable } \\
\hline.. $\ln ($ migration rate between country $i$ and $j$ ) & $\log$ of ratio of maritime migrants from country $i$ to country $j$ to the population of country $j$ \\
\hline \multicolumn{2}{|l|}{ Geographical variables } \\
\hline $\ln ($ distance $)$ & $\log$ of average distance travelled by migrants \\
\hline common border dummy & a dummy variable: 1 if common border, 0 otherwise \\
\hline length of coast & length of coast in $\mathrm{km}$ \\
\hline \multicolumn{2}{|l|}{ Population variables } \\
\hline ln (share of port-city population) & $\log$ of (port city population/total population) \\
\hline common language dummy & an indicator variable: 1 if common language, 0 otherwise \\
\hline \multicolumn{2}{|l|}{ Market-related variables } \\
\hline $\ln$ (market potential) & $\log$ of market potential \\
\hline labour productivity of maritime sector & measured by ton/man ratio \\
\hline \multicolumn{2}{|l|}{ Previous migration } \\
\hline migrants in 1700 & number of migrants in 1700 \\
\hline
\end{tabular}

Sources: see text

Note: Right hand side variables are defined from the point of view of the destination countries. 
As Table 2 shows, the group of market characteristics consists of two variables: labour productivity, a variable we use as a proxy for maritime wages, and market potential, an indicator which captures the economic viability and strength of the destination country's maritime sector. Earlier we explained that the early modern maritime labour market was characterised by relatively few barriers to the international movement of workers and, by the eighteenth century, consisted chiefly of wage labourers. Based on the basic model of migration (Ravenstein [1885] 1889; cf. Greenwood 1975; Borjas 1989), which assumes that in such circumstances migration is driven by the attractive force exerting itself from origin to destination and is impeded by the cost of moving between the two locales, one would expect that these factors would also be important determinants of migration in the early modern maritime sector. In the next group of variables we will touch upon the issue of cost, but the two variables in this group serve as indicators of the attractiveness of the labour market in the destination countries. In our analysis we use level of labour productivity in the maritime sector as a proxy for maritime wages, which unfortunately are very scarce for this period (Van Royen et al. 1997; Blakemore 2017). Labour productivity has been shown to have increased substantially during early modern times, in many cases outstripping productivity growth in other sectors (Lucassen and Unger 2011). ${ }^{8}$ Like wage levels, this new capacity for labour productivity offered opportunities for the economic betterment of incoming migrants. Market potential is also expected to have a positive effect on migration, capturing as it does the

\footnotetext{
${ }^{8}$ The improvement in productivity was chiefly the result of increases in technology and in the skill levels of the workforce. In this paper we use estimates of labour productivity provided by Van Lottum (2014). The index of productivity used in this study is a tonnage per man ratio, and is - as indicated in the previous section - calculated using data from the PPD. Van Lottum's study provides labour productivity estimates only for the following countries: Portugal, Italy, France, Belgium, Ireland, England, Scotland, Spain, Denmark, Norway, the Netherlands, Sweden, and Germany.
} 
economic viability and strength of the destination country's maritime sector, and hence its potential to enable migrants to achieve some degree of economic success. We calculate market potential as a weighted average of the population of all countries in our sample in which the weights are the inverse of the distance between the countries. ${ }^{9}$ Research on twentieth-century Europe has shown that market potential has a positive effect on migration: migrants follow market potential (cf. Crozet 2004).

The group of geographical characteristics include three variables: the distance between the country of origin and the destination country, an indicator of a common border between the destination and the country of origin, and the length of coastline. The first two variables are general explanatory variables of migration, the last one is sector-specific. In our analysis migration distance is used as a proxy for the cost of migration - the second variable in the basic migration model, as mentioned above. ${ }^{10} \mathrm{We}$ expect this variable to have a negative effect on

\footnotetext{
${ }^{9}$ Since we analyses the maritime sector, the distances are calculated between the major seaports of the countries. Population size is based on data provided by Clio Infra, source:
} https://www.clioinfra.eu/Indicators/TotalPopulation.html\#datasets.

${ }^{10}$ Migration distance can be calculated in numerous ways. The most straightforward option we consider is the calculation of straight-line Euclidean distance (or 'as the crow flies'), which is calculated by measuring the distance between the geometric centres of the countries of origin and destination. The longitude and latitude of the country centroids, necessary to calculate Euclidean distance are based on: https://www.pdx.edu/econ/countrygeography-data. Other varieties we consider record the distance between the largest seaports, or the distance between the capitals of the respective countries, based on De Vries (1984). An alternative way of measuring the distance, and more closely related to the actual distances travelled by the migrants, is the distance between country of origin and destination travelled over sea (the sea route), using the largest port of the country of origin and destination as point of departure and arrival, respectively. Here De Vries' (1984) urbanisation estimates are used to determine the largest port cities for each country in 1700 and 1800; the distance travelled by sea is calculated using the tool available on: http://ports.com/sea-route/. For obvious reasons, no such distance could be calculated for countries lacking direct access to sea, which in our dataset applies to Switzerland and Ukraine (as Note 2 indicates, two countries for which we have data available only for 1800). Our preferred measure is this last one, 
migration. The second factor in this group of geographical characteristics is the existence of a common border between the origin and destination country. Empirical studies on international migration in the twentieth century find a strong positive effect exerted by countries with shared borders as compared to non-contiguous nations: common borders encourage international migration (Mayda 2010; Artuc et al., 2015, cf. Helliwell, 1997, 1998). In these studies, common borders are usually treated as a proximity indicator. We expect that maritime migrants in the early modern period were also more likely to have moved to neighbouring countries. However, because our data stems chiefly from maritime nations, and because travel by ship was an important mode of (long-distance) travel in the early modern period, it is also possible that our analysis will be limited in its ability to show the effect of this variable.

The third variable, the length of a country's coastline, is used as an indicator of a nation's maritime potential. ${ }^{11}$ Our hypothesis is that countries with long coastlines present more possibilities for an individual employed in the maritime trade, and will therefore have a positive effect on migration in this sector of the economy. For instance, one can expect countries with large coastlines to have more ports and better maritime infrastructure, and as a result they are likely to offer more employment possibilities for those engaged in this branch, thus stimulating the immigration of foreign seamen.

The first variable in the group of language and population variables is the total size of (sea)port populations. ${ }^{12}$ Like the previous variable, this also captures a country's maritime potential, but it investigates as well an important premise of the basic gravity model of

\footnotetext{
but, as robustness check, we have also used the other three measures of the distance between the origin and destination countries, as will be discussed in the next section.

${ }^{11}$ The length of coastline is provided by the CIA World Factbook: https://www.cia.gov/library/publications/theworld-factbook/. As explained in note 6, no data is available for Switzerland and Ukraine.

12 The size of port population is based on De Vries' (1984) urbanisation figures.
} 
migration: namely that, ceteris paribus, the population size of a given destination has an important (positive) effect on migrations, because of the larger labour market for immigrants in more populated locales (Lewer and Van den Berg 2007). ${ }^{13}$ Because we take a sectoral approach our analysis, in contrast to most general studies we home in on the population of port cities, because this aspect most effectively represents the destination labour market.

Linguistic characteristics are captured by a binary variable indicating whether the destination and the country of origin share a common language. ${ }^{14}$ Our hypothesis is that the presence of a common language has a positive effect on migration. First, a common language lowers the transaction costs of migration because, facilitates a better exchange of information, it is one of the factors that makes the settling process less burdensome. Second, fluency in the language of the host nation is also likely to make an individual more desirable for a prospective employer, as it facilitates a better transfer of one's skills to the labour market (Adserà, 2015). Language characteristics of origin and destination countries have received attention from studies analysing contemporary migration (e.g. Adserà and Pytliková 2015), but not in the research on early modern migration. Some studies of early modern migrations consider the role of other migrants in the destination country who speak the same language (see, for instance, Kuijpers 2005; Moch 2003; Janssen, 2016; cf. Lesger et.al 2002). But these works primarily discuss the value of migration networks in facilitating information (something we capture with the previous migration variable, to be discussed next) rather than, specifically, the linguistic

\footnotetext{
13 For 1700 the total size of port city populations could not be calculated for Norway and Northern Ireland; as De Vries applies a minimal size of 5.000 inhabitants, the populations of the main ports in these countries were too small to be included in his dataset. As mentioned in note 6, Switzerland and Ukraine lacked direct access to sea, therefore no data was available for these countries.

${ }^{14}$ This is based on the majority language in a country, source: https://www.cia.gov/library/publications/the-worldfactbook/.
} 
similarities between countries, as is usually the case in studies on contemporary population flows.

Our final group concerns one variable: the stock of previous migration. This variable captures the existing network of migrants in the destination country. ${ }^{15}$ We expect the stock of previous migration to have a positive effect on later migration. This follows from both modern and early modern research. In the latter it has been identified as an important determinant of international migration flows; migrants already settled abroad are thought to have facilitated the migration and settlement of compatriots (Moch 2003; Hoerder 2002; Janssen 2016). However, unlike the extensive research on international migration in the nineteenth century (see in particular Wegge 1998; Hatton and Williamson 1998), the approach to early modern migration has chiefly been qualitative. Studies have offered detailed qualitative accounts of the importance of migration networks created by previous migrants in providing information about economic possibilities in foreign destinations (Lucassen 1987) and the way such information was transmitted between 'home' and 'abroad' (Sogner and Van Lottum 2007). Our study, however, offers the first quantitative assessment of this potentially important phenomenon for the early modern period.

\section{Regression Analysis}

Using the explanatory variables discussed in the previous section, and summarised in Table 2, our regression specification is as follows:

$\ln \left(\right.$ migrates $\left._{i j}\right)=\alpha+\beta_{1}$ Geo $_{j}+\beta_{2}$ Pop $_{j}+\beta_{3}$ Market $_{j}+\beta_{4}$ PreviousMigr $_{j}+\gamma_{i}+\delta_{j}+\varepsilon_{i j}$

\footnotetext{
15 The stock of migrants from ca., 1700 captures the long-run effect of migration networks established in the destination country. It is possible that the effect operates through the established business connection that lasted across several generations.
} 
where migrates $i j$ is migration rates of maritime workers from country $i$ to country $j$ defined as the ratio of maritime migrants from country $i$ to country $j$ to the population of country $j$; variables Geo $_{j}$, Pop $_{j}$, Market $j_{j}$, PreviousMigr ${ }_{j}$ denote the vectors of geographical, population and linguistic, market, and previous migration variables; $\gamma_{i}$ and $\delta_{j}$ are origin and destinationcountry indicator variables, and $\varepsilon_{i j}$ is error term. We estimate equation (1) with OLS and use heteroscedasticity-robust standard errors. The consistency of the estimator requires all variables to be exogenous. Admittedly, some of the variables related to the population, market potential, and labour productivity might be endogenous. Therefore, we decided to be conservative and will interpret our results as indicators of important multivariate correlations rather than of necessarily causal relationship.

We also consider the issue of multicollinearity among the explanatory variables. Correlation coefficients among the variables revealed that only the correlation between market potential and labour productivity in the maritime sector might give rise to the multicollinearity issue (correlation is about 0.7), therefore we estimated equation (1) with each of them separately as well as together. Correlations among other variables are low: even the correlation between market potential and distance is only about 0.4 . Despite the inevitably high correlation between the market potential and the labour productivity of the maritime sector, we conjecture that they each capture different factors affecting migration flows. Market potential may be a proxy for economic opportunities opened up to the maritime sector, but these may not be immediate. Labour productivity in the maritime sector, on the other hand, captures monetary gains, which are more immediate than those gains offered by market potential.

Figure 3: International Maritime Migration in 1700, Unconditional Correlations 
1700

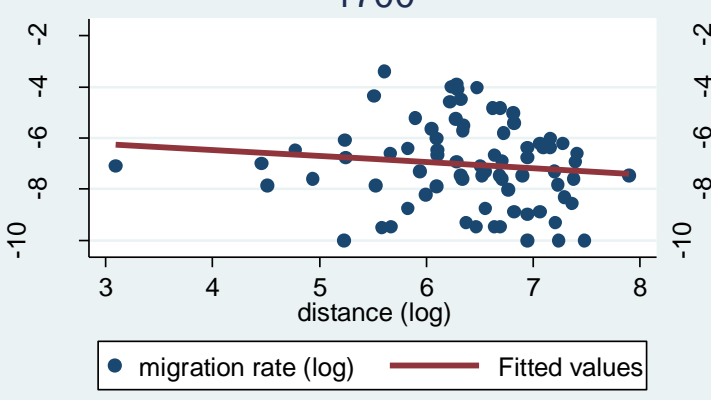

1700

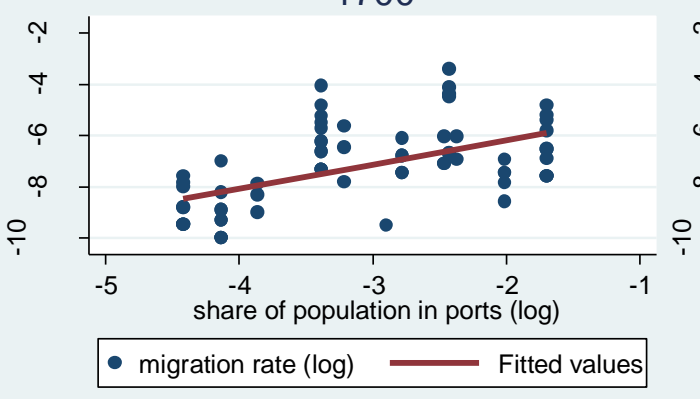

1700

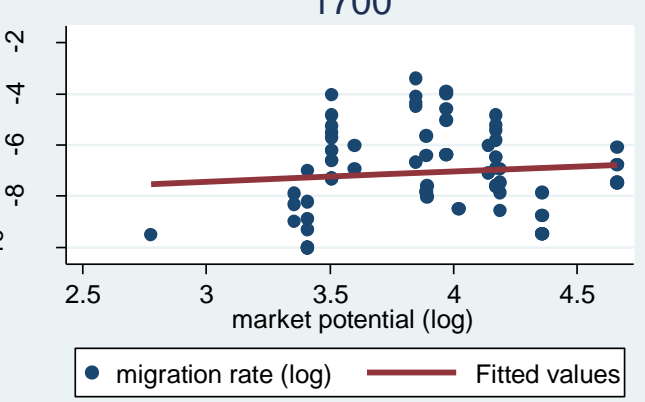

1700

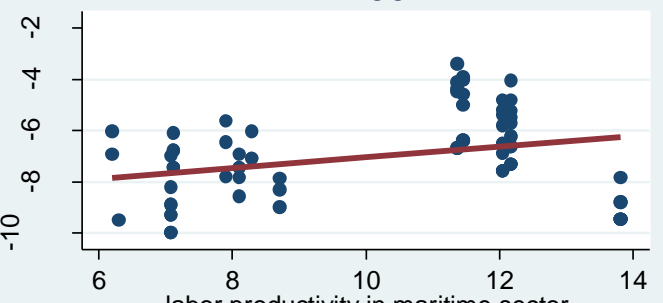

labor productivity in maritime sector

- migration rate $(\mathrm{log})$ Fitted values

Figure 4: International Maritime Migration in 1800, Unconditional Correlations

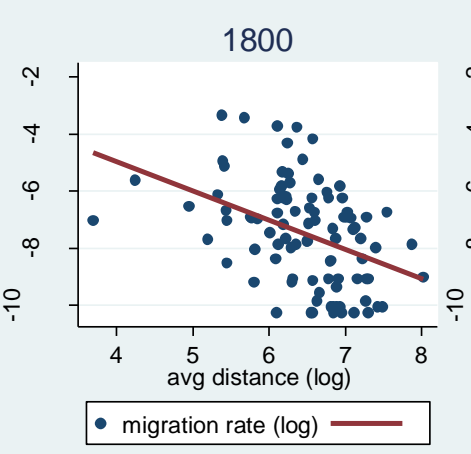

1800

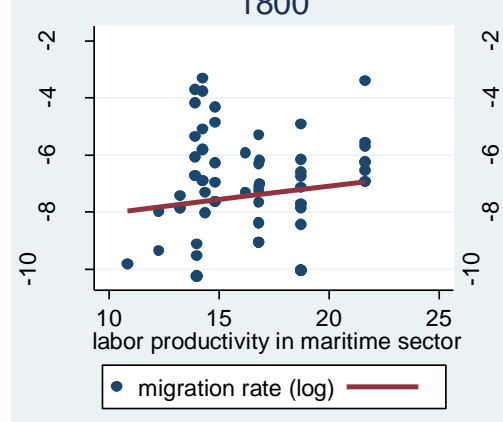

1800

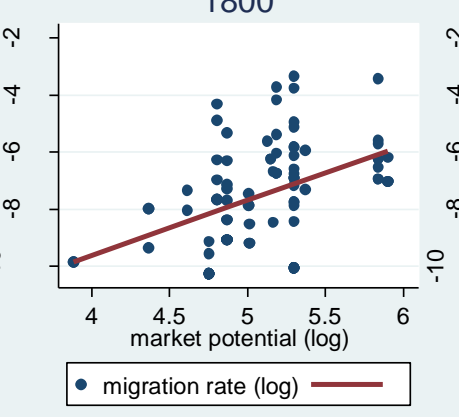

1800

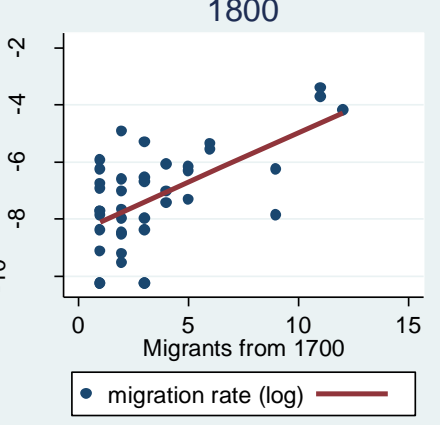

1800

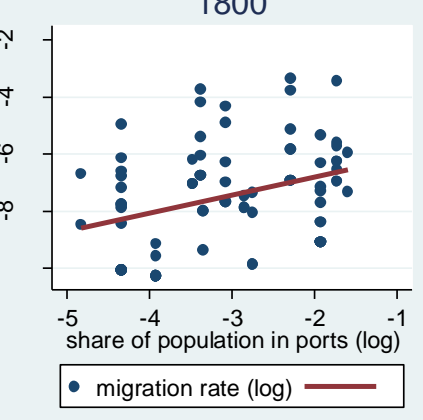

- migration rate $(\log )$ 
Before we present the regression results, we will discuss several graphs that outline a relationship between the migration rates and a few explanatory variables. Figures 3 and 4 show relationships between the migration rates and the distance between origin and destination countries, the share of population in ports, labour productivity in the maritime sector, market potential, and previous migration for the respective years of 1700 and 1800 . We see that the migration rates are negatively related to the distance between the country of origin and that of destination, confirming our prior belief that distance inhibits migration. The share of population in ports and labour productivity is positively related to migration, which suggests that the larger the ports are, the more attractive they become for maritime migrants. We also observe a positive correlation between labour productivity and migration rates, suggesting the importance of economic betterment on the intensity of migration. Lastly, Figure 4 indicates a strong relationship between the stock of maritime migrants in 1700 and migration rates in 1800 . This suggests a rather impressive persistence effect of past generations of maritime migrants and onto later cohorts. Overall, Figures 3 and 4 also show that despite different magnitudes, the correlations between the examined variables and migration rates have the same direction: a remarkable stability, considering the interval between the two periods under scrutiny spans about one hundred years. ${ }^{16}$

Though important and revealing, the graphs discussed in the previous paragraph show simple, unconditional correlations. Multivariate analysis is required to gain further insight into the complexity of factors influencing maritime migration. Therefore, we use regression analysis and estimate equation (1) to shed further light on the determinant of cross-country maritime migration rates. We estimate equation (1) for the respective years of 1700 and 1800 and present various specifications to check the robustness of our findings. We will first discuss

\footnotetext{
${ }^{16}$ It is possible that that the British ships were less present in the south, which would potentially undercount migration from the southern Europe. We have conducted the regression analysis without Spain and Portugal and the results are qualitatively unchanged (they are available from the authors upon request).
} 
whether the estimated relationships are statistically significant and whether they are positive or negative; then we will discuss their relative importance; finally, in the next section, we will offer possible explanations of these results. 
Table 3. International Maritime Migration in 1700, Regression Analysis.

\begin{tabular}{|c|c|c|c|c|c|c|c|}
\hline Variables & $\mathrm{I}$ & II & III & IV & $\mathrm{V}$ & VI & VII \\
\hline \multicolumn{8}{|l|}{ Geography } \\
\hline \multirow[t]{2}{*}{$\ln ($ distance $)$} & $-0.90 * * *$ & $-0.90 * * *$ & $-0.85 * * *$ & $-0.85 * * *$ & $-0.85 * * *$ & $-0.85 * * *$ & $-0.85 * * *$ \\
\hline & {$[0.240]$} & {$[0.240]$} & {$[0.246]$} & {$[0.251]$} & {$[0.251]$} & {$[0.251]$} & {$[0.251]$} \\
\hline \multirow[t]{2}{*}{ common border dummy } & $-0.42 *$ & $-0.42 *$ & -0.34 & -0.34 & -0.34 & -0.34 & -0.34 \\
\hline & [0.249] & [0.249] & {$[0.320]$} & {$[0.351]$} & {$[0.351]$} & {$[0.350]$} & {$[0.350]$} \\
\hline \multirow{2}{*}{ length of coast } & & $0.0001 * * *$ & -.00002 & 0.00002 & 0.000006 & 0.00001 & 0.00001 \\
\hline & & {$[.0001]$} & {$[.00002]$} & {$[0.00002]$} & {$[0.00003]$} & {$[0.00003]$} & {$[0.00002]$} \\
\hline \multicolumn{8}{|c|}{ Population and linguistic characteristics } \\
\hline \multirow[t]{2}{*}{ ln (share of port-city population) } & & & $0.59 * * *$ & $0.59 * * *$ & $1.08 * * *$ & $1.03 * * *$ & $1.11 * * *$ \\
\hline & & & [0.139] & [0.143] & {$[0.181]$} & [0.167] & {$[0.186]$} \\
\hline \multirow[t]{2}{*}{ common language dummy } & & & & 0.03 & 0.03 & 0.02 & 0.02 \\
\hline & & & & {$[0.397]$} & {$[0.397]$} & {$[0.396]$} & {$[0.396]$} \\
\hline \multicolumn{8}{|l|}{ Market characteristics } \\
\hline \multirow[t]{2}{*}{$\ln ($ market potential) } & & & & & $1.57 * * *$ & & $1.43 * * *$ \\
\hline & & & & & [0.289] & & {$[0.310]$} \\
\hline \multirow[t]{2}{*}{ labour prod. maritime sector } & & & & & & 0.07 & 0.04 \\
\hline & & & & & & {$[0.076]$} & {$[0.061]$} \\
\hline \multirow[t]{2}{*}{ Constant } & $-3.85^{* *}$ & -2.21 & 0.17 & 0.15 & $-5.60 * *$ & -1.71 & $-7.22 * * *$ \\
\hline & {$[1.646]$} & {$[1.806]$} & {$[1.760]$} & {$[1.820]$} & {$[2.169]$} & {$[1.667]$} & {$[1.891]$} \\
\hline Origin and Destination Country FE & YES & YES & YES & YES & YES & YES & YES \\
\hline Observations & 77 & 77 & 70 & 70 & 70 & 68 & 68 \\
\hline R-squared & 0.868 & 0.868 & 0.863 & 0.863 & 0.863 & 0.862 & 0.862 \\
\hline
\end{tabular}


Table 3 presents the results for the year 1700 . We see that distance is always statistically significant and negatively related to the migration rates, whereas other geographical characteristics - a common border and the length of coast - are mostly insignificant. ${ }^{17}$ In the first two specifications, the presence of a common border seems to have a negative and significant effect but the statistical significance disappears in the remaining five specifications. As for the population and linguistic characteristics, the share of population living in port towns is always significantly related to maritime migration, whereas common language has no significant impact. ${ }^{18}$ Market characteristics exhibit a similar pattern qualitatively: labour productivity does not exert a significant impact, and market potential is always positively and significantly related to maritime migration. ${ }^{19}$

\footnotetext{
${ }^{17}$ We have conducted extensive robustness checks with respect to the distance measure and estimated all regressions specification with three other distance measures: straight-line Euclidean distance calculated as the distance between the geometric centres of the countries of origin and destination; sea routes between the countries; and distance betlween the capitals of the countries. In all cases, the distances have negative and significant impact on the migration rates.

18 As a robustness check, we have used Colomer Matutano language similarity index (see: http://jordic.com/langsim/), which measures the degree of similarity between shows the degree of similarity between 10.556 words in 28 languages. The similarity between two languages is defined as the average standarized Levenshtein distance between pairs of words. Since the results were very similar to the ones with a common language dummy, we report only the former one. The results using language similarity index are available from the authors upon request.

${ }^{19}$ As a robustness check, we have used distances between the countries' capitals and between the countries' centroids, respectively. Since the results were qualitatively unchanged, we do not present them here but they are available from the authors upon request.
} 
Table 4. International Migration in 1800, Regression Analysis.

\begin{tabular}{|c|c|c|c|c|c|c|c|c|c|}
\hline Variables & I & II & III & IV & $\mathrm{V}$ & VI & VII & VIII & IX \\
\hline & \multicolumn{9}{|c|}{ Geography } \\
\hline \multirow[t]{2}{*}{ ln (distance) } & $-0.68 * * *$ & $-0.67 * *$ & $-0.67 * * *$ & $-0.61 * *$ & $-0.61 * *$ & $-0.61 * *$ & $-0.61 * *$ & -0.78 & -0.78 \\
\hline & {$[0.241]$} & [0.249] & [0.246] & {$[0.243]$} & {$[0.243]$} & {$[0.241]$} & {$[0.241]$} & [0.607] & {$[0.601]$} \\
\hline \multirow[t]{2}{*}{ common border dummy } & 0.42 & 0.47 & 0.47 & 0.45 & 0.45 & 0.45 & 0.45 & 0.3 & 0.3 \\
\hline & {$[0.404]$} & {$[0.440]$} & {$[0.435]$} & [0.444] & [0.444] & {$[0.446]$} & {$[0.446]$} & {$[0.460]$} & {$[0.462]$} \\
\hline \multirow[t]{3}{*}{ length of coast } & & $0.00004^{*}$ & $0.00007 * * *$ & $0.0001 * * *$ & $0.0001 * * *$ & $0.0002 * * *$ & $0.0001 * * *$ & $0.00008 * * *$ & $0.0001 * *$ \\
\hline & & [0.00002] & [0.00002] & {$[0.00003]$} & {$[0.00002]$} & {$[0.00003]$} & {$[0.00003]$} & [0.00002] & [0.00005] \\
\hline & \multicolumn{9}{|c|}{ Population and Linguistic Characteristics } \\
\hline \multirow{2}{*}{ ln (share of port-city population) } & & & $0.82 * * *$ & -0.06 & $0.39 * * *$ & $0.36^{*}$ & $0.35^{*}$ & $0.60 * *$ & 0.29 \\
\hline & & & {$[0.155]$} & [0.302] & {$[0.137]$} & [0.198] & [0.197] & {$[0.282]$} & {$[0.242]$} \\
\hline \multirow[t]{3}{*}{ common language dummy } & & & & 0.49 & 0.49 & 0.49 & 0.49 & 0.5 & 0.5 \\
\hline & & & & [0.308] & [0.308] & {$[0.308]$} & [0.308] & [0.489] & {$[0.486]$} \\
\hline & \multicolumn{9}{|c|}{ Market Characteristics } \\
\hline \multirow[t]{2}{*}{ ln (market potential) } & & & & & $2.00 * * *$ & & 0.75 & 0.63 & \\
\hline & & & & & {$[0.356]$} & & {$[0.490]$} & {$[0.832]$} & \\
\hline \multirow[t]{3}{*}{ labour productivity of maritime sector } & & & & & & $0.42 * * *$ & $0.26 * *$ & & 0.23 \\
\hline & & & & & & {$[0.078]$} & [0.117] & & {$[0.175]$} \\
\hline & \multicolumn{9}{|c|}{ Previous Migration } \\
\hline migrants in 1700 & & & & & & & & $0.09 * *$ & $0.09 * *$ \\
\hline & & & & & & & & [0.032] & {$[0.033]$} \\
\hline \multirow[t]{2}{*}{ Constant } & -3.38 & $-4.15 * *$ & -0.89 & $-6.05 * *$ & $-14.21 * * *$ & $-12.99 * * *$ & $-14.02 * * *$ & -5.75 & -7.59 \\
\hline & {$[2.044]$} & [1.897] & [1.955] & [2.437] & [2.679] & [2.513] & {$[2.704]$} & [8.912] & {$[5.170]$} \\
\hline Origin and Destination Country FE & YES & YES & YES & YES & YES & YES & YES & YES & YES \\
\hline Observations & 94 & 88 & 86 & 86 & 86 & 84 & 84 & 50 & 48 \\
\hline R-squared & 0.824 & 0.817 & 0.815 & 0.819 & 0.819 & 0.818 & 0.818 & 0.929 & 0.928 \\
\hline
\end{tabular}

Sources: see text; $* * * \mathrm{p}<0.01, * * \mathrm{p}<0.05, * \mathrm{p}<0.1$ 
Table 4 presents the results for the year 1800. As for the geographical characteristics, we see that, again, distance has negative and significant effect on the rates of maritime migration. However, unlike in the year 1700, the length of coastline does exhibit a significant and positive effect on the migration rates. The existence of a common border remains an insignificant factor. The effect of population and linguistic characteristics remain qualitatively unchanged relative to the year 1700. Common language has no significant effect, and again the share of the population in port towns is positively related to migration, although not in all specifications. Market characteristics show very interesting and different results in comparison with the year 1700. First, labour productivity in the maritime sector becomes statistically significant, even in the specification including market potential. Market potential, on the other hand, is significant only in the specification without labour productivity, a major difference relative to 1700 . Both factors - market potential and labour productivity - lose statistical significance once we include previous migration. This, capturing the effect of migration networks, is positively related to the migration flows in 1800. A word of caution is required here. As we see in Table 3, because of lack of data, the number of observations in columns VII and IX drops when considering previous migration. Therefore, our conclusions need to be considered as tentative; more research is needed to firmly establish the effect of previous migrations on international migration of maritime workers in early modern times. 
Table 5. Standardized Beta Coefficients, International Migration in 1700.

\begin{tabular}{|c|c|c|c|c|c|c|c|}
\hline Variables & I & II & III & IV & V & VI & VII \\
\hline \multicolumn{8}{|c|}{ Geography } \\
\hline $\ln ($ distance $)$ & -0.44 & -0.44 & -0.44 & -0.44 & -0.44 & -0.44 & -0.44 \\
\hline common border dummy & -0.12 & -0.12 & -0.1 & -0.11 & -0.11 & -0.1 & -0.1 \\
\hline length of coast & & 0.52 & -0.05 & -0.05 & 0.02 & 0.04 & 0.04 \\
\hline \multicolumn{8}{|c|}{ Population and Linguistic Characteristics } \\
\hline In (share of port-city population) & & & 0.34 & 0.34 & 0.63 & 0.58 & 0.63 \\
\hline common language dummy & & & & 0.01 & 0.01 & 0.01 & 0.01 \\
\hline \multicolumn{8}{|c|}{ Market Characteristics } \\
\hline In (market potential) & & & & & 0.42 & & 0.38 \\
\hline labour productivity of maritime sector & & & & & & 0.11 & 0.07 \\
\hline Observations & 77 & 77 & 70 & 70 & 70 & 68 & 68 \\
\hline R-squared & 0.868 & 0.868 & 0.863 & 0.863 & 0.863 & 0.862 & 0.862 \\
\hline
\end{tabular}

Sources: see text 
Table 6. Standardized Beta Coefficients, International Migration in 1800

\begin{tabular}{|c|c|c|c|c|c|c|c|c|c|}
\hline Variables & I & II & III & IV & $\mathrm{V}$ & VI & VII & VIII & IX \\
\hline & \multicolumn{9}{|c|}{ Geography } \\
\hline $\ln ($ distance $)$ & -0.27 & -0.26 & -0.25 & -0.23 & -0.23 & -0.22 & -0.22 & -0.29 & -0.28 \\
\hline common border dummy & 0.12 & 0.13 & 0.13 & 0.12 & 0.12 & 0.12 & 0.12 & 0.09 & 0.09 \\
\hline \multirow[t]{2}{*}{ length of coast } & & 0.15 & 0.29 & 0.48 & 0.37 & 0.65 & 0.54 & 0.29 & 0.41 \\
\hline & \multicolumn{9}{|c|}{ Population and Linguistic Characteristics } \\
\hline In (share of port-city population) & & & 0.44 & -0.03 & 0.21 & 0.19 & 0.18 & 0.32 & 0.14 \\
\hline \multirow[t]{2}{*}{ common language dummy } & & & & 0.12 & 0.12 & 0.12 & 0.12 & 0.11 & 0.11 \\
\hline & \multicolumn{9}{|c|}{ Market Characteristics } \\
\hline In (market potential) & & & & & 0.47 & & 0.18 & 0.14 & \\
\hline \multirow[t]{2}{*}{ labour productivity of maritime sector } & & & & & & 0.61 & 0.39 & & 0.34 \\
\hline & \multicolumn{9}{|c|}{ Previous Migration } \\
\hline migrants in 1700 & & & & & & & & 0.28 & 0.28 \\
\hline Observations & 94 & 88 & 86 & 86 & 86 & 84 & 84 & 50 & 48 \\
\hline R-squared & 0.824 & 0.817 & 0.815 & 0.819 & 0.819 & 0.818 & 0.818 & 0.929 & 0.928 \\
\hline
\end{tabular}

Sources: see text 
Until now, we have focused on the statistical significance and sign of the relationship between the factors influencing the migration rates. Before we discuss the results emerging from Tables 3 and 4 in greater detail, it is important to establish the relative importance of each of the factors, in addition to their statistical significance. To do this, we have calculated standardized beta coefficients, which express the estimated coefficients as standardized coefficients with mean of 0 and standard deviation of 1 . This allows us to compare the magnitudes of all the estimated coefficients, thus establishing their relative importance. Table 5 shows the beta coefficients for the year 1700, Table 6 for the year 1800 . We see that in 1700 , out of the statistically significant variables (highlighted in italics), the population of port towns has the largest impact, followed by distance and then market potential. In 1800 , the relative importance of variables differs across specifications, but if we consider the most advanced specifications (column IX), then the length of coastline exhibits the largest effect, followed by past migration stock and distance.

\section{Discussion of the findings}

The multivariate analysis in the previous section offers insights into the factors affecting the international migration flows of maritime workers at the beginning and the end of the eighteenth century. Though we expressed some caution, our assessment showed that previous migration appears to have been an important migration factor for maritime workers at the end of the eighteenth century. This conclusion confirms studies of the transatlantic mass migrations of the nineteenth century, which regard prior migration as a key factor in explaining the size and direction of international migration (Baines 1994; Hatton and Williamson 1998). It also supports our conjecture about the role of maritime migrants who were already living in the destination country. Several reasons may account for the importance of this factor. Maritime 
migrants already residing in a destination country can provide information about the maritime labour market in that country, as well as local labour market conditions more broadly and information about travel costs and search costs related to the finding of work (Lucassen 1987; Hoerder 2002; Moch 2003). These resident migrants can also help would-be migrants cover travel costs through remittances; the costs of looking for work in a new country can be lowered through resident migrants' offers of lodging or monetary loans while a newcomer searches for work (Hatton and Williamson 1998; Bade 2003). Furthermore, this resident-migrant group can help with assimilation to local conditions and might also present potential marriage partners, thus lowering the emotional costs related to the relocation to a new country (Sogner and Van Lottum 2007). Our analysis shows the remarkably persistent effects exerted by migrant networks on migration patterns during the eighteenth century. ${ }^{20}$

Apart from clarifying the effect of this specific and important variable, the general picture that emerges from our analysis is that economic opportunities and the costs of migration alike crucially affected migratory patterns. Economic opportunities were captured by a relatively direct indicator such as labour productivity (as a proxy for wage levels), but market potential, the population of ports, and the length of a country's coastline can also be regarded as indicators of the relative attractiveness of the destination country for maritime migrants. That our analysis shows that a large share of maritime migrants acting as rational economic actors, seeking to maximise their income by moving to areas with better opportunities, supports the characterisation of the early modern maritime labour market that has been provided in the field's historiography. As explained earlier, the literature (chiefly of a qualitative nature) suggests that, facilitated by a relative paucity of migration barriers, the early modern maritime labour market predominantly comprised proletarians who sought to optimise their earnings by

\footnotetext{
${ }^{20}$ On the workings of migration networks consisting of individuals with a shared occupation, see: Lesger et.al 2002 and Schrover et.al 2007.
} 
migrating to those areas that offered the chance for them to do so, even if these locales were situated abroad. Our regression analysis confirms this picture, and thus shows that the basic mechanisms behind a crucial sector of the pre-industrial economy were not dissimilar to those of international labour markets in the modern era. This conclusion is an important finding.

When shifting our view from the general outcome of our exercise, and zooming in on the separate outcomes of our analysis for 1700 and 1800 , we find the general picture that emerges from our analysis to be, indeed, relatively uniform. But as the previous section made clear, there are also notable differences in the significance and ranking of the variables. These distinctions partly result from our inclusion of the previous migrants variable, which makes market potential and labour productivity insignificant. But even when we compare the most extensive specification in 1700 with its counterpart in 1800 there are noticeable differences. Such differences are particularly salient with regard to our finding that our proxy for wage levels, labour productivity, had a significant effect in 1800 (as we expected) but not in 1700 (which was surprising).

As (potential) wage-gain opportunities are at the core of general migration theory, and qualitative studies on the early modern period have also emphasised the importance of wage differentials in explaining international migration flows, it is indeed surprising that in 1700 our most direct indicator of the latter factor is insignificant. This might be explained by the lack of chances for (direct) economic betterment through potential higher wages, probably because there was relatively little demand in the key hubs and thus relatively little competition in the international labour market. Figure 1 showed that international migration increased substantially by the end of the eighteenth century, and competition among centres became severe (Van Lottum 2011, 2015). But the lack of chances for monetary betterment was compensated (at least to some extent) by the existence of (diverse) job opportunities in port cities and possible opportunities to trade, as captured by the port population size and variables, 
respectively, both of which are significant and appear in comparatively high positions in the ranking of beta coefficients for 1700 .

A final issue following from our analysis that merits discussion concerns the applicability of 'modern' explanatory variables to this early modern case study. From our analysis, it follows that variables such as the past migration variable, migration distance and the population of port cities are indicators (or types of indicators) that explain international migration both in the modern and early modern contexts. Our analysis, however, also showed that common language and common borders, two factors that have been demonstrated to be important for the industrial and post-industrial eras, did not assert a significant effect on international migrations in the eighteenth-century maritime sector. This, too, is a relevant finding, which needs further discussion.

In the case of common language, we believe that its statistical insignificance has two explanations. The first is sector-specific. Although sharing a common language among workers is arguably more important for highly skilled professions than for the tasks performed by semiskilled or unskilled maritime labourers (Artuc 2014), as Rediker (1987) argues, the labour process in the maritime sector possessed a very specific, and chiefly technical vocabulary - a maritime lingua franca largely based on Dutch terms - which one needed to master to be successful in the sector. Traditional language barriers, therefore, played a lesser role as long as workers could speak this sector-specific language. Given that, as Figure 2 showed, most maritime workers had been born on or near the coast in their home countries, many would have been exposed to the maritime sector, and its specific vocabulary, from an early age (cf. Bruijn 1997).

The second explanation for the negligibility of common language as a factor relates to the state of European languages in the eighteenth century: compared to the nineteenth and twentieth centuries, early modern (western) European languages were not as uniform and were 
not so strictly demarcated from one another. Languages and dialects did not stop at their respective national borders, and because dialects could differ considerably even within countries, it was common for compatriots not to be able to communicate with one another (Heerma van Voss 1996). This means that by assigning national languages to countries - as we did for the purposes of our analysis - we may have not done justice to the complexity of language in the early modern context.

In the case of insignificance of the common borders variable, the non-importance of the presence of a common border with regard to a migrant's decision to move is likely explained by the fact that in the early modern context it does not capture proximity effectively. As we suggested earlier, travel by sea was a very common mode of transportation in the early modern period; indeed, moving over land to a contiguous country may have been far more cumbersome and costly than travelling to another foreign destination that was easily reached by ship. For instance, from a locality in Denmark it may have been much easier (i.e., quicker, cheaper) to sail to the northern Netherlands than to travel from northern Germany. In such a case, a shared border does not accurately capture proximity as a factor.

\section{Concluding remarks}

The three migrant seamen this paper started with were anything but exceptional: hey were part of an increasingly mobile population. This paper represents the findings of the first rigorous quantitative analysis of the determinants of international labour migration in early modern Europe in one of its most important sectors - maritime sector. What drove migrants such as Alström, Eehler and Faber to take up employment in another country? To answer this question we relied on a unique source of maritime migrants which allowed us to construct international migration flows of maritime workers. These international migration flows were then used to 
analyse the effects of past migrations and of the geographic, population, linguistic, and market characteristics of European countries.

Our multivariate analysis showed that the basic mechanisms driving labour migration in the early modern maritime sector were largely comparable to those found in the modern era. That factors such as a shared language and border did not have a significant effect on international migration is likely the result of the early modern context being different from that of the nineteenth and twentieth centuries. However, the general picture that emerges from our analysis is that workers in this sector largely behaved as rational actors, benefitting from economic opportunities abroad if these became available. To do so, they were facilitated by their relative freedom of movement and a free mode of recruitment. We found that variables that captured economic opportunities, such as labour productivity (our proxy for wage levels) and the relative size and population of port cities, stimulated migrations, while - as one would expect - distance deterred the international movement of labour. Moreover, also confirming studies on nineteenth- and twentieth-century international migration, we found that the stock of previous migration also appeared to have been an important factor in determining later migrations. $^{21}$

Overall, we believe our analysis to rest on three important contributions. First, we mentioned in the introduction that international labour mobility is still an under-researched topic. Studies taking a social-science approach are especially rare: most research is of a qualitative nature. The outcome of our regression analysis of data stemming from the maritime sector therefore provides a much-needed quantitative perspective on the underlying mechanisms governing the movement of hundreds of thousands of labour migrants who sought better lives for themselves outside their home countries.

\footnotetext{
${ }^{21}$ Interestingly, as Tables 5 and 6 indicates distance was more important in 1700 than in 1800. This was likely to be the result of a combination of improved infrastructure (roads), but certainly also an increase in trade volume and traffic between ports: more ships travelled between the various ports which made it easier (and cheaper) to go from A to B.
} 
Moreover, it is important to note that although the maritime sector has been hailed as one of the first modern international labour markets (Rediker 1987; Lucassen 1997), it was by no means the only sector in which wage labour was the rule, and international mobility common. Europe in the eighteenth century was undergoing rapid processes of proletarianisation and (as result) experienced increasing levels of labour mobility - internal and international. One can therefore expect to find that mechanisms similar to what we revealed in our analysis of the maritime sector played a role in other sectors of the early modern economy. More research is of course necessary to test the validity of this hypothesis.

But there is a broader reason why we believe the outcome of our analysis matters, and here we arrive at the third important contribution of this paper. In a seminal paper published in the Journal of Global History in 2009, Lucassen and Lucassen (see also Lucassen and Lucassen 2010, 2017) argued against what has become known as the mobility transition thesis, a theory formulated in 1971 by the geographer Wilbur Zelinsky. This theory argued that the industrial era demarcated a clear break with the early modern period; only with the advent of modernisation did the European population become truly mobile. Presenting new estimates of pre-industrial migration rates (Lucassen and Lucassen 2009; Lucassen and Lucassen 2010), the two authors refuted this claim; they demonstrated that before industrialisation European populations had already been highly mobile and that the transition to modernisation did not result in a substantial break (i.e., a take-off) in migration levels. Nevertheless, before this paper there had been no rigorous analyses of the driving forces behind early modern international migration, and very little was known about whether the transition to industrialisation implied any change in the nature and extent of international migration. Of course our study showed that there were some differences between the key drivers of international migration flows in the early modern period and those of the industrial era, and more research on other sectors is 
necessary to draw broader conclusions. However, our analysis indicates that there was much more continuity than change between the early modern and modern eras.

\section{References}

Acemoglu, D., S. Johnson, and J.A. Robinson (2005) "The Rise of Europe: Atlantic Trade, Institutional Change and Economic Growth.” American Economic Review (95): 546-579.

Adserà, A. (2015) “Language and culture as drivers of migration.” IZA World of Labor (164).

Adserà, A., and Pytliková, M. (2015) "The Role of Language in Shaping International Migration.” The Economic Journal (125): 49-81.

Artuc, E., Docquier, F., Özden, Ç., and Parsons C. (2015) “A Global Assessment of Human Capital Mobility: The Role of Non-OECD Destinations.” World Development (65): 6-26.

Bade, K. J. (2003) Migration in European History. Oxford: Blackwell.

Bade, K.J., P.C. Emmer, L. Lucassen and J. Oltmer, eds. (2011) The Encyclopedia of European Migration and Minorities: From the Seventeenth Century to the Present. Cambridge: Cambridge University Press.

Baines, D. (1994) “European Emigration, 1815-1930: Looking at the Emigration Decision Again.” Economic History Review (47): 525-44. 
Blakemore, R.J. (2017) 'Pieces of eight, pieces of eight: seamen's earnings and the venture economy of early modern seafaring.” Economic History Review (70): 1153-1184.

Borjas, J.G. (1989) “Economic Theory and International Migration.” International Migration Review (23): 457-85.

Bruijn, J.R. (1997) “Career patterns”, in P.C. Royen, J.R. Bruijn and J. Lucassen (eds.), ‘Those emblems of hell'? European sailors and the maritime labour market, 1570-1870. St. John's: International Maritime Economic History Association: 25-34.

Cottret, B.J. (1992) The Huguenots in England: Immigration and Settlement c.1550-1700. Cambridge: Cambridge University Press.

Crozet, M. (2004) "Do Migrants Follow Market Potentials? An Estimation of a New Economic Geography Model.”Journal of Economic Geography (4) : 439-58.

De Vries, J. (1984) European Urbanization (1500-1800). Cambridge, MA: Harvard University Press.

Gelderblom, O. (2000) Zuid-Nederlandse kooplieden en de opkomst van de Amsterdamse stapelmarkt (1578-1630). Hilversum: Verloren.

Greenwood, M. (1975) "Research on internal migration in the United States: a survey." Journal of Economic Literature (13): 397-433. 
Grubb, F., (2011) German immigration and servitude in America, 1709-1920. New York: Routledge.

Hatton, T.J., and J.G. Williamson (1998) The Age of Mass Migration: Causes and Economic Impact. New York and Oxford: Oxford University Press.

Hatton, T.J., and J.G. Williamson (2008) Global Migrations and the World Economy: Two Centuries of Policy and Performance. Cambridge, MA: MIT Press.

Heerma van Voss, L. (1996) "North Sea Culture." in J. Roding and L. Heerma van Voss (eds.) The North Sea and Culture (1550-1800). Verloren: Hilversum: 21-40.

Helliwell. J.F. (1997) “National borders, trade and migration.” Pacific Economic Review (2): $165-185$.

Helliwell, J.F. (1998) How Much Do National Borders Matter? Washington, DC: Brookings Institution.

Hoerder, D. (2002) Cultures in Contact. World Migrations in the Second Millenium. Durham and London: Duke University Press.

Israel, J.I. (1985) European Jewry in the Age of Mercantilism, 1550-1750. Oxford: Clarendon. 
Janssen, G. (2016) The Dutch Revolt and Catholic Exile in Reformation Europe. Cambridge: Cambridge University Press.

Karamera, D., V. Iwuagwu Oguledo and B. Davis (2002) “A Gravity Model Analysis of International Migration to North America.” Applied Economics (32): 1745-1755.

Kitch, M.J. (1986) "Capital and Kingdom: Migration to Later Stuart London.” in A.L. Beier and R. Finlay (eds.) London 1500-1700: The Making of the Metropolis, edited by, 224-51. Harlow: Longmans.

Kuijpers, E. (2005) Migrantenstad. Immigranten en sociale verhoudingen in 17e-eeuws Amsterdam. Verloren: Hilversum.

Lesger, C. (2006) "Informatiestromen en de herkomstgebieden van migranten in de Nederlanden in de vroegmoderne tijd." Tijdschrift voor Sociale en Economische Geschiedenis (3): 3-23.

Lesger, C., Lucassen, L., Schrover, M. (2002) "Is there life outside the migrant network? German immigrants in XIXth century Netherlands and the need for a more balanced migration typology.” Annales de démographie historique (2): pp. 29-50.

Lewer, J., and H. van den Berg (2007) “A Gravity Model of Immigration.” Economics Letters (99): 164-67. 
Lucassen, J. and L. Lucassen (2009) “The Mobility Transition Revisited, 1500-1900: What the Case of Europe Can Offer to Global History.” Journal of Global History (4): 347-77.

Lucassen, J. and L. Lucassen (2010) “The mobility transition in Europe revisited, 1500-1900. Sources and methods." IISH Research paper (46).

Lucassen, J. and L. Lucassen (2017) "Theorizing Cross-Cultural Migrations: The Case of Eurasia since 1500.” Social Science History (41): 445-475.

Lucassen, J. and Unger, R.W. (2011) "Shipping, Productivity and Economic Growth.” in R.W. Unger (ed.) Shipping and Economic growth, 1350-1850. Leiden and Boston: Brill.

Lucassen, J. (1987) Migrant Labour in Europe, 1600-1900: The Drift to the North Sea. London: Croom Helm.

Lucassen, J. (1996) “The North Sea: A Crossroad for Migrants?” in J. Roding and L. Heerma van Voss (eds.) The North Sea and Culture (1550-1800). Hilversum: Verloren: 168-84.

Lucassen, J. (2002) “Immigranten in Holland, 1600-1800 een kwantitatieve benadering." CGM Working Paper (3).

Lucassen, L. (2012) “Cities, States and Migration Control in Western Europe: Comparing Then and Now.” In B. de Munck and A. Winter (eds.) Gated Communities? Regulating Migration in Early Modern Cities. Farnham: Ashgate: 217-40 
Manning, P. (2005) Migration in World History. New York and London: Routledge.

Mayda, A.M. 2007) "International migration: A panel data analysis of the determinants of bilateral flows." CreAM Discussion Paper Series (7).

McCants, A. (1992) "Internal Migration in Friesland, 1750-1805." The Journal of Interdisciplinary History (22): 387-409

Page Moch, L. (2003) Moving Europeans: Migration in Western Europe since 1650.

Bloomington: Indiana University Press.

Pettegree, A. (1986) Foreign Protestant Communities in Sixteenth-Century London. Oxford: Clarendon.

Ravenstein, E.G. (1885; 1889) “The Laws of Migration.” Journal of the Royal Statistical Society (48):167-222, and (52): 214-301.

Rediker, M. (1989) Between the Devil and the Deep Blue Sea. Cambridge: Cambridge University Press.

Ruderman, D.B. (2010) Early Modern Jewry: A New Cultural History. Princeton: Princeton University Press. 
Schilling, H. (1983) "Innovation through Migration: The Settlements of Calvinistic

Netherlanders in Sixteenth- and Seventeenth-Century Central and Western Europe. Histoire Sociale, Social History (16): 7-33.

Sogner, S., (1993) 'Young in Europe: Norwegian Sailors and Servant-Girls Seeking Employment in Amsterdam.” in J.P. Bardet, F. Lebrun, and J. Dupâquier (eds.) Mesurer et comprendre. Mélanges offerts a Jacques Dupâquier. Paris: Presses Universitaires de France: $515-32$

Sogner, S., and J. van Lottum. "An Immigrant Community? Norwegian Sailors and Their Wives in $17^{\text {th }}$-century Amsterdam. History of the Family 12, no. 3 (2007): 153-68.

Van Lottum, J., and J.L.van Zanden. "Labour Productivity and Human Capital in the European Maritime Sector of the Eighteenth Centur.” Explorations in Economic History 53 (2014): 83100.

Van Lottum, J., Heerma van Voss, L., and Lucassen, J. "Sailors, National and International Labour Markets and National Identity, 1600-1850.” In Shipping Efficiency and Economic Growth 1350-1800, edited by Richard Unger. Leiden and Boston: Brill, 2011.

Van Lottum, J., Across the North Sea: The Impact of the Dutch Republic on International Labour Migration, c. 1550-1850. Amsterdam: Aksant, 2007.

Van Lottum, J. "Labour Migration and Economic Performance: London and the Randstad, c. 1600-1800." Economic History Review 64, no 2 (2011): 531-70. 
Van Lottum, J. "Some Thoughts about Migration of Maritime Workers in the EighteenthCentury North Sea Region.” International Journal of Maritime History 27 (2015): 647-61.

Van Royen, P.C., J.R. Bruijn and J. Lucassen (eds.) (1997) “Those Emblems of Hell”? European Sailors and the Maritime Labour Market, 1570-1870. St. John's, Newfoundland: International Maritime Economic History Association.

Wegge, S.A. (1998) “Chain Migration and Information Networks: Evidence from Nineteenth-Century Hesse-Cassel.” Journal of Economic History (58): 957-86.

Wegge S.A. (1999) "To part or not to part? Emigration and inheritance institutions in nineteenth-century Hesse-Cassel.” Explorations in Economic History (36): 33-55.

Wegge S.A. (2017) “Different Profiles, Different Choices: Mid-Nineteenth Century Hessians Who Emigrated to the Southern Hemisphere.” Social Science History 41 (3), 415-444.

Wegge S.A. (2018) "Eighteenth-century German emigrants from Hanau-Hesse: Who Went East and Who Went West." Continuity and Change 33 (2), 225-253.

Wokeck, M.S. (1999) Trade in Strangers: The Beginnings of Mass Migration to North America. Pennsylvania: The Pennsylvania State University Press. 